\title{
GROWTH CHARACTERISTICS AND SURVIVAL RATE OF PUREBRED AND CROSSBRED LAMBS UNDER UNLIMITED SUCKLING REGIME
}

\author{
M. ABD-ALLAH
}

Animal Production Department, Faculty of Agriculture, Al-Azhar University, Assiut Branch, PO Box 7111, Assiut, Egypt.

\section{ABSTRACT}

Received at: 29/9/2012

Accepted: 14/11/2012
Seventy purebred and crossbred lambs were used in this study to investigate the effect of some factors affecting growth traits, daily gains and survival rates of lambs under unlimited suckling regime. Ewes in the flock were not milked and lambs were subjected to unlimited suckling regime without weaning. Results showed that, variation among breed groups were significant $(\mathrm{P}<0.01)$ in birth, 6, 9 months and yearling weights, as well as, at $3^{\text {rd }}$ months was a significant $(\mathrm{P}<0.05)$. Male born lambs were significantly heavier $(\mathrm{P}<0.01)$ than females except at $3^{\text {rd }}$ months. Type of birth or the ages of dam have no significant effect on body weights in all ages except at birth, where it was significant. Breed of lambs have a significant effect on the average daily gains, while there was no significant effect of sex, type of birth or age of dam, except at the period from $3^{\text {rd }}$ to $6^{\text {th }}$ months. The superiority of crossbreed lambs over their parental breeds from birth to yearling age ranged between 2.18 and $1.65 \%$ from birth to yearling. Likewise, the daily gain of crossbred lamb groups during the four periods studied, have the same results. Breed of lambs have a significant effect $(\mathrm{P}<0.05)$ on the survival rate of lambs, since the survival rate of Rahmani lambs was higher at the early stages of life while the crossbred lambs showed superiority in survival rate with advancing age. Sex did not have any significant effect on the survival rate, except at birth. Type of birth and the age of ewes had a highly significant effect on survival rates in all periods studied except at the age of a year. It is concluded that Chios breed could be an appropriate breed for terminal sire crossbreeding to improve both Rahmani ewe's productivity and early lamb growth under Upper Egypt conditions system.

Key words: Rahmani sheep, Chios sheep, crossbreeding, growth performance, survival rate

\section{INTRODUCTION}

Weaning time is a critical and important stage in the life of lambs, however lambs at weaning are exposed to weaning shock, and lambs need to return to the normal growth rate. Also, animals subjected to a period of undernutrition often exhibit very high growth during subsequent realimentation (McManus et al., 1972; Thornton et al., 1979). This phenomenon, known as compensatory growth, has very important implications in countries that depend largely on grazing to support animal production (Drew and Reid, 1975). Growth performance of lambs is the most important characteristics in lamb production, crossbreeding is one of the methods commonly used for improving the efficiency of productive traits. The positive effects of crossbreeding on growth performance of lambs have been reported by several investigators (Rastogi et al., 1993; Hassan and El-Feel, 1988; Morsy, 2002; AbdAllah, 2005).
The economic benefit of sheep production can be enhanced by increasing the efficiency of lamb growth to the desired market weight. Fast and efficient lamb growth to reach heavier market weight is a basic issue for efficient sheep production. Judging efficiency can be achieved through evaluating growth traits including, birth weight, weaning weight and growth rate. Body weight of lambs is strongly influenced by breed, sex, birth type, age of dam, and season of lambing (Tuah and Baah, 1985; Gatenby, 1986 and Rastogi et al., 1993). Most researchers studied the effects of these factors on the growth rates and in the application of weaning at different ages. This study aimed to study the effect of these factors on the growth without any effect of weaning.

The purpose of this study was to compare the growth performance and survival rates of purebred and crossbred lambs to determine the effect of breed. Another goal of the study is to examine the impact of 
some of the other factors such as sex, type of birth and the age of dams on the growth performance and survival rates in lambs under Unlimited Suckling Regime.

\section{MATERIALS and METHODS}

\section{Location and experimental design:}

This study was carried out during the period from August, 2009 to May, 2011 at the experimental farm of the Animal Production Department, Faculty of Agriculture, AL-Azhar University, Assiut Branch. A total number of 70 lambs (18 Rahmani (R), 16 Chios (C), $191 \frac{1}{2} \mathrm{C}_{1 / 2} \mathrm{R}$ and $17 \mathrm{1} / 2 \mathrm{R} 1 / 2 \mathrm{C}$ lambs) resulting from 66 pregnant ewes (34 Rahmani and 32 Chios). Animals were housed under semi-open sheds. Ewes were mated for the first time at age of one year and rams at two years. At lambing, new born lambs were kept with their dams in lambing pens, dams were weighed at the $4^{\text {th }}$ day after parturition and birth weight of lambs was recorded after $24 \mathrm{hr}$ from parturition, Ewes in the flock were not milked and lambs were subjected to unlimited suckling regime without weaning. Live weights of the lambs were recorded at bi-weekly intervals until an average of one year of age. Interpolation was applied to calculate average live weight at certain ages and increase in daily live weights between certain periods. Lambs were gradually fed on starter feeding (ground corn $70 \%$, decorticated cotton seed meal $20 \%$, Soya bean meal $8.0 \%$, calcium carbonate $1.5 \%$, salt $0.5 \%$ ), and Egyptian clover (Trifolium Alexandrinum) in winter and green maize plants and crop residues in summer were available for grazing ewes and also for lambs. Ewes were supplemented with pelleted CFM starting with $1 / 2 \mathrm{~kg} / \mathrm{head} /$ day and increased to $3 / 4 \mathrm{~kg} / \mathrm{head} /$ day during late pregnancy and lactation periods. The concentrate pelleted diet containing (Maize 30\%, ground corn $30 \%$, wheat bran $15 \%$, decorticated cotton seed meal $15 \%$, molasses $3 \%$, limestone $1.5 \%$, salt $0.5 \%$ ). blocks of minerals and vitamins mixtures were also provided. However, fresh and clean water is available at all times. The flock was sheared twice yearly on April (spring) and September (autumn). They were subjected to routine vaccination program against infections diseases (foot and mouth disease, Rift fever valley, sheep pox and clostridium disease). The flock was also injected and drenched against internal and external parasites.

\section{Statistical Analysis:}

Some environmental factors affecting the growth characteristics of lambs, like genotype (breed), lamb sex, birth type and age of dams were investigated using least-square procedure (SAS, 1998). Duncan test was utilized for determining differences among subgroups means. Comparisons between the groups with regard to lamb survival rates were made using chi-square method (Düzgünęs et al., 1987). After the elimination of the effects of genotype, sex, birth type and age of dam lamb survival rates were calculated. Analysis was performed according to the following linear model: $\quad \mathbf{Y}_{\mathrm{ijklm}}=\boldsymbol{\mu}+\mathbf{B}_{\mathrm{i}}+\mathbf{S}_{\mathrm{j}}+\mathbf{T}_{\mathrm{k}}+\mathbf{A}_{\mathrm{l}}+\mathbf{e}_{\mathrm{ijklm}}$

Where: $\mathbf{Y}_{\mathrm{ijklm}}=$ studied trait, $\mu=$ overall mean, $\mathbf{B}_{\mathrm{i}}=$ fixed effect of the $i^{\text {th }}$ breed ( $\mathrm{i}=$ Rahmani, Chios, CR and $\mathrm{RC}$ lambs), $\mathbf{S}_{\mathrm{j}}=$ fixed effect of the $\mathrm{j}^{\text {th }}$ sex of lamb ( $j=$ male and female), $\mathbf{T}_{k}=$ fixed effect of the $k^{\text {th }}$ lamb birth type ( $\mathrm{k}=$ single and twin), $\mathbf{A}_{\mathrm{l}}=$ fixed effect of the $1^{\text {th }}$ age of dam $(1=1,2,3,4$ and 5) where. $1=$ $2 \mathrm{yr}-$ old or less, $2=<3 \mathrm{yr}-$ old, $3=<4 \mathrm{yr}-$ old, $4=<$ $5 \mathrm{yr}-\mathrm{old}$, and $5=>5 \mathrm{yr}-\mathrm{old}$., $\mathbf{e}_{\mathrm{ijklm}}=$ effect of the $\mathrm{m}^{\text {th }}$ random error. Factors under investigation were assumed to be fixed, except the error term, which was assumed to be random and normally distributed ( 0 and $\delta^{2}$ ).

Superiority percentage $\left.=\left(\bar{Y}_{c} / \sum b_{i} Y_{i}\right)-1\right) \times 100$ Where: $\bar{Y}_{c}=$ average performance of the cross, $Y_{i}=$ average performance of the purebreds involved in the cross $C$, and $b_{i}=$ blood percentage of the $i^{\text {th }}$ breed in the cross $\mathrm{C}$.

\section{RESULTS}

\section{Growth performance of lambs.}

Least-squares means and their standard errors of body weights of Rahmani, Chios, and F1 crossbred lambs are presented in Table (1). Variation among breeding groups were significant $(\mathrm{P}<0.01)$ at birth, $6^{\text {th }}, 9^{\text {th }}$ months and yearling weights, as well as, at $3^{\text {rd }}$ months was a significant $(\mathrm{P}<0.05)$. Birth weight of Rahmani lambs and $1 / 2 \mathrm{C} 1 / 2 \mathrm{R}$ crossbreed lambs showed a higher than Chios or $1 / 2 \mathrm{R} 1 / 2 \mathrm{C}$ lambs. At $6^{\text {th }}$ months, weights of Chios and $F_{1}$ crossbred lambs tended to be heavier than those of Rahmani lambs. Males were significantly $(\mathrm{P}<0.05)$ heavier than female at birth, as it was a highly significant effect of sex at the age of 6 , 9 months and one year. Single born lambs was significantly $(\mathrm{P}<0.01)$ heavier at birth than twin $(3.62$ $\mathrm{kg}$ vs. $3.07 \mathrm{~kg}$ ) born lambs. Single born lambs, also maintained high body weights at ages of 3, 6, 9 and 12 months without significant differences. Age of dam had a significant effect $(\mathrm{P}<0.01)$ on birth weight. The effect of age of dam on body weights at 3, 6, 9 months and yearling weights was not significant. 
Table 1: Least-squire means \pm standard error of some factors affecting the growth characteristics of purebred and crossbred lambs.

\begin{tabular}{|c|c|c|c|c|c|}
\hline Item & $\begin{array}{c}\text { Birth weight } \\
\text { (kg) }\end{array}$ & $\begin{array}{c}3^{\text {rd }} \text { month live } \\
\text { weight }(\mathrm{kg})\end{array}$ & $\begin{array}{c}6^{\text {th }} \text { month live } \\
\text { weight (kg) }\end{array}$ & $\begin{array}{c}9^{\text {th }} \text { months live } \\
\text { weight }(\mathrm{kg})\end{array}$ & $\begin{array}{c}\text { Yearling weight } \\
(\mathrm{kg})\end{array}$ \\
\hline Overall mean & $3.35 \pm 0.49$ & $16.57 \pm 1.48$ & $24.16 \pm 1.99$ & $34.57 \pm 2.36$ & $41.77 \pm 2.39$ \\
\hline Breed group & $* *$ & $*$ & $* *$ & $* *$ & $* *$ \\
\hline Rahmani (R) & $3.57 \pm 0.14^{\mathrm{a}}$ & $16.44 \pm 0.46^{\mathrm{ab}}$ & $25.52 \pm 0.62^{b}$ & $32.33 \pm 0.73^{c}$ & $38.67 \pm 0.74^{d}$ \\
\hline Chios (C) & $3.30 \pm 0.14^{\mathrm{ab}}$ & $15.75 \pm 0.45^{b}$ & $26.08 \pm 0.61^{b}$ & $33.77 \pm 0.72^{b c}$ & $40.85 \pm 0.73^{c}$ \\
\hline $1 / 2$ C $1 / 2 \mathrm{R}$ & $3.51 \pm 0.14^{b}$ & $16.76 \pm 0.51^{\mathrm{ab}}$ & $26.83 \pm 0.69^{b}$ & $35.13 \pm 0.82^{b}$ & $42.77 \pm 0.83^{b}$ \\
\hline $1 / 2 \mathrm{R} 1 / 2 \mathrm{C}$ & $3.01 \pm 0.13^{c}$ & $17.33 \pm 0.41^{\mathrm{a}}$ & $28.19 \pm 0.56^{\mathrm{a}}$ & $37.04 \pm 0.66^{\mathrm{a}}$ & $44.79 \pm 0.67^{\mathrm{a}}$ \\
\hline Sex of lambs & $*$ & Ns & $* *$ & $* *$ & $* *$ \\
\hline Male & $3.50 \pm 0.09$ & $16.98 \pm 0.32$ & $27.66 \pm 0.44$ & $35.61 \pm 0.52$ & $42.96 \pm 0.52$ \\
\hline Female & $3.19 \pm 0.12$ & $16.16 \pm 0.41$ & $25.65 \pm 0.55$ & $33.52 \pm 0.65$ & $40.58 \pm 0.66$ \\
\hline Type of birth & $* *$ & Ns & ns & $\mathrm{ns}$ & Ns \\
\hline Single & $3.62 \pm 0.07$ & $16.64 \pm 0.22$ & $26.99 \pm 0.30$ & $35.07 \pm 0.35$ & $42.33 \pm 0.36$ \\
\hline Twins & $3.07 \pm 0.15$ & $16.50 \pm 0.54$ & $26.32 \pm 0.73$ & $34.06 \pm 0.86$ & $41.20 \pm 0.87$ \\
\hline Age of dam & $* *$ & $\mathrm{Ns}$ & ns & ns & Ns \\
\hline$\leq 2$ yr-old or less & $2.94 \pm 0.137^{b}$ & $16.51 \pm 0.48$ & $26.30 \pm 0.65$ & $33.99 \pm 0.78$ & $40.99 \pm 0.79$ \\
\hline$\leq 3$ yr-old & $3.70 \pm 0.154^{\mathrm{a}}$ & $16.98 \pm 0.47$ & $27.09 \pm 0.63$ & $34.96 \pm 0.75$ & $41.88 \pm 0.76$ \\
\hline$\leq 4 \mathrm{yr}$-old & $3.35 \pm 0.141^{\mathrm{ab}}$ & $16.66 \pm 0.47$ & $27.06 \pm 0.64$ & $34.95 \pm 0.76$ & $42.05 \pm 0.76$ \\
\hline$\leq 5 \mathrm{yr}$-old & $3.35 \pm 0.124^{\mathrm{ab}}$ & $16.21 \pm 0.38$ & $26.46 \pm 0.52$ & $34.02 \pm 0.61$ & $40.86 \pm 0.62$ \\
\hline$>5 y r-o l d$ & $3.40 \pm 0.243^{\mathrm{a}}$ & $16.49 \pm 0.76$ & $26.38 \pm 1.02$ & $34.91 \pm 1.21$ & $43.04 \pm 1.23$ \\
\hline
\end{tabular}

$* \mathrm{P}<0.05 ; * * \mathrm{P}<0.01$, means values with different letters are significantly different at $\mathrm{P}<0.05$

\section{Average daily gain (ADG)}

Results in Table (2) indicate that there is a significant increase in daily growth rates correspond with the increase in the weights of lambs, where we find that there are significant differences $(\mathrm{P}<0.05)$ of daily growth rates in the first phase and the second phase of the age, as well as increasing the differences between these breeds with advantage of age. Despite of the superiority of males to females in body weights, but there were no significant differences between males and females in average daily gains in all stages of growth, with the exception of the second stage of growth where there are significant differences $(\mathrm{P}<0.05)$. Type of birth did not have any significant effect on the average daily gains of lambs, although there are differences in these gains for the benefit of individual lambs born. The age of mother also did not have any significant effect on the average daily gains, where daily gains rates were comparable at every stage of growth.

Table 2: Least-squire means \pm standard error of some factors affecting average daily gains $(\mathrm{g})$ of purebred and crossbred lambs under unlimited suckling regime.

\begin{tabular}{|c|c|c|c|c|}
\hline Item & ADG1 (g) & ADG2 (g) & ADG3 (g) & ADG4 (g) \\
\hline Overall mean & $146.3 \pm 16.5$ & $112.1 \pm 17.2$ & $87.89 \pm 12.4$ & $80.00 \pm 10.2$ \\
\hline Breed group & $*$ & $*$ & $* *$ & $* *$ \\
\hline Rahmani (R) & $142.4 \pm 5.18^{b}$ & $100.9 \pm 5.38^{b}$ & $75.64 \pm 3.87^{c}$ & $70.36 \pm 3.21^{\mathrm{c}}$ \\
\hline Chios $(\mathrm{C})$ & $138.5 \pm 5.10^{b}$ & $114.8 \pm 5.30^{\mathrm{ab}}$ & $85.43 \pm 3.82^{b}$ & $78.64 \pm 3.16^{b c}$ \\
\hline $1 / 2$ C $1 / 2 R$ & $146.2 \pm 5.77^{b}$ & $111.9 \pm 5.99^{\mathrm{ab}}$ & $92.13 \pm 4.31^{\mathrm{ab}}$ & $84.92 \pm 3.58^{\mathrm{ab}}$ \\
\hline $1 / 2 \mathrm{R}^{1 / 2 \mathrm{C}}$ & $158.1 \pm 4.66^{\mathrm{a}}$ & $120.7 \pm 4.85^{a}$ & $98.37 \pm 3.49^{\mathrm{a}}$ & $86.07 \pm 2.89^{\mathrm{a}}$ \\
\hline Sex of lambs & ns & $*$ & Ns & Ns \\
\hline Male & $149.2 \pm 3.65$ & $118.7 \pm 3.79$ & $88.30 \pm 2.73$ & $81.64 \pm 2.27$ \\
\hline Female & $143.4 \pm 4.60$ & $105.5 \pm 4.78$ & $87.49 \pm 3.44$ & $78.36 \pm 2.85$ \\
\hline Type of birth & ns & ns & Ns & Ns \\
\hline Single & $144.3 \pm 2.51$ & $115.1 \pm 2.61$ & $89.76 \pm 1.88$ & $80.66 \pm 1.56$ \\
\hline Twins & $148.3 \pm 6.09$ & $109.1 \pm 6.32$ & $86.02 \pm 4.55$ & $79.34 \pm 3.77$ \\
\hline Age of dam & $\mathrm{ns}$ & $\mathrm{ns}$ & Ns & Ns \\
\hline$\leq 2 \mathrm{yr}-$ old or less & $149.4 \pm 5.47$ & $108.8 \pm 5.68$ & $85.35 \pm 4.09^{a b}$ & $77.78 \pm 3.39^{b}$ \\
\hline$\leq 3 \mathrm{yr}-$ old & $147.4 \pm 5.29$ & $112.3 \pm 5.49$ & $87.52 \pm 3.95^{a b}$ & $77.05 \pm 3.28^{b}$ \\
\hline$\leq 4 \mathrm{yr}-$ old & $147.3 \pm 5.33$ & $115.5 \pm 5.53$ & $87.75 \pm 3.98^{a b}$ & $78.87 \pm 3.30^{b}$ \\
\hline$\leq 5 \mathrm{yr}$-old & $142.2 \pm 4.34$ & $113.8 \pm 4.50$ & $84.04 \pm 3.24^{b}$ & $76.03 \pm 2.69^{b}$ \\
\hline$>5 \mathrm{yr}$-old & $145.1 \pm 8.53$ & $109.9 \pm 8.86$ & $94.80 \pm 6.38^{a}$ & $90.27 \pm 5.29^{a}$ \\
\hline
\end{tabular}

$* \mathrm{P}<0.05 ; * * \mathrm{P}<0.01$, means values with different letters are significantly different at $\mathrm{P}<0.05$. ADG1 $=\left(3^{\text {rd }}\right.$ month weight- birth weight $) / 90) \times 1000 ; \mathrm{ADG} 2=\left(6^{\text {th }}\right.$ month weight- $3^{\text {rd }}$ month weight $\left./ 90\right) \times 1000$ ADG3 $=\left(9^{\text {th }}\right.$ month weight- $6^{\text {th }}$ month weight 190) $\times 1000 ;$ ADG4 $=\left(\right.$ yearling weight $-9^{\text {th }}$ month weight $) / 90 \times 1000$ 
The superiority of $F_{1}$ crossbreed lambs $\left(1 / 2 C^{1 / 2} R\right.$ and $1 / 2 \mathrm{R} 1 / 2 \mathrm{C}$ ) over their parental breeds from birth to yearling age, except at birth for $1 / 2 \mathrm{R} 1 / 2 \mathrm{C}$ crossbred lambs. It ranged between 2.18 and $1.65 \%$ from birth to yearling. However, crossbred $1 / 2 \mathrm{R} \quad 1 / 2 \mathrm{C}$ lambs did not show any superiority for parents in the birth weight. Likewise, daily gain of $F_{1}$ crossbred lambs groups during the four periods studied, generally showed superiority than that of their parental pure breeds which ranged between 3.76 and $22.15 \%$.

Table 3: Superiority percent of body weights and daily gain of different crossbred lambs over their parental breed groups.

\begin{tabular}{|c|c|c|}
\hline Breed crosses & $1 / 2$ C $1 / 2 \mathbf{R}$ & $1 / 2 \mathbf{R}^{1 / 2} \mathbf{C}$ \\
\hline \multicolumn{3}{|l|}{ Body weight } \\
\hline Birth weight & 2.18 & -12.37 \\
\hline $3^{\text {rd }}$ live body weight & 4.13 & 7.67 \\
\hline $9^{\text {th }}$ live body weight & 6.29 & 12.07 \\
\hline Yearling weight & 7.57 & 12.65 \\
\hline \multicolumn{3}{|l|}{ Average daily gain } \\
\hline ADG2 & 3.76 & 11.92 \\
\hline ADG3 & 14.4 & 22.15 \\
\hline ADG4 & 13.99 & 15.53 \\
\hline
\end{tabular}

\section{Lambs survival rate:}

Results for survival rate from birth to yearling age are presented in Table (4). At birth, Rahmani and $1 / 2 \mathrm{R} 1 / 2 \mathrm{C}$ lambs had significantly $(\mathrm{P}<0.05)$ higher survival rate than Chios and $1 / 2 \mathrm{C} 1 / 2 \mathrm{R}$ lambs, The same trend was observed at the $3^{\text {th }}$ month of age, with an increased survival rate in cross resulting from Chios mothers and there are no significant differences between breeds. At $6^{\text {th }}$ months of age was observed that there has been a significant improvement in the survival rate in crossbred lambs higher than parents.

Male and female lambs did not have significantly different survival rates from three months to 6,9 and 12 months of age (Table 4). However, both sexes have maintained survival rates when you reach the yearling age. Single born lambs had significantly higher survival rate than twins at birth (96.15 vs. $83.33 \%), 3^{\text {rd }}$ months of age $(98.0$ vs. $80.0 \%)$ and $6^{\text {th }}$ months of age (100.0 vs. $83.33 \%)$. However, twin born lambs had maintained their high survival rate after $6^{\text {th }}$ month to yearling. Age of dam had a significant effect on survival rate of lambs at birth, $3^{\text {rd }}, 6^{\text {th }}$ and $9^{\text {th }}$ months of age, while the effect was not significant at yearling age. The survival rates was higher for lambs born to mothers ages about three or 4 years than lambs born from maiden ewes (2 years or less), or lambs born from older ewes (5 years or more) and retained a high survival rate with advancing age.

Table 4: Some factors affecting survival rates of purebred and crossbred lambs from birth to yearling under unlimited suckling regime.

\begin{tabular}{|c|c|c|c|c|c|c|c|c|c|c|}
\hline \multirow{3}{*}{$\begin{array}{l}\text { Classification } \\
\text { Breed group } \\
\end{array}$} & \multicolumn{10}{|c|}{ Survival rates $\%$ at the age } \\
\hline & \multicolumn{2}{|c|}{ At birth } & \multicolumn{2}{|c|}{$3^{\text {rd }}$ Months } & \multicolumn{2}{|c|}{$6^{\text {th }}$ Months } & \multicolumn{2}{|c|}{$9^{\text {th }}$ Months } & \multicolumn{2}{|c|}{ at yearling } \\
\hline & $\mathbf{N}$ & $*$ & $\mathbf{N}$ & Ns & $\mathbf{N}$ & $*$ & $\mathbf{N}$ & $*$ & $\mathbf{N}$ & ns \\
\hline Rahmani (R) & 18 & $94.44^{(5.56)}$ & 17 & $94.12^{(5.88)}$ & 16 & $93.75^{(6.25)}$ & 15 & $93.33^{(6.67)}$ & 14 & 100.00 \\
\hline Chios (C) & 16 & $93.75^{(6.25)}$ & 15 & $93.33^{(6.67)}$ & 14 & $92.86^{(7.14)}$ & 13 & 100.00 & 13 & 100.00 \\
\hline $1 / 2 \mathrm{C} 1 / 2 \mathrm{R}$ & 19 & $89.47^{(10.53)}$ & 17 & $94.12^{(5.88)}$ & 16 & 100.00 & 16 & 100.00 & 16 & 100.00 \\
\hline $1 / 2 \mathrm{R} 1 / 2 \mathrm{C}$ & 17 & $94.12^{(5.88)}$ & 16 & $93.75^{(6.25)}$ & 15 & 100.00 & 15 & 100.00 & 15 & 100.00 \\
\hline Sex of lambs & & * & & ns & & ns & & Ns & & ns \\
\hline Male & 38 & $94.74^{(5.26)}$ & 36 & $94.44^{(5.56)}$ & 34 & $97.06^{(2.94)}$ & 33 & 100.00 & 33 & 100.00 \\
\hline Female & 32 & $90.63^{(9.38)}$ & 29 & $93.10^{(6.90)}$ & 27 & $96.30^{(3.70)}$ & 26 & $96.15^{(3.85)}$ & 25 & 100.00 \\
\hline Type of birth & & $* *$ & & $* *$ & & $* *$ & & Ns & & ns \\
\hline Single & 52 & $96.15^{(3.85)}$ & 50 & $98.00^{(2.00)}$ & 49 & 100.00 & 49 & $97.96^{(2.04)}$ & 48 & 100.00 \\
\hline Twins & 18 & $83.33^{(16.67)}$ & 15 & $80.00^{(20.0)}$ & 12 & $83.33^{(16.67)}$ & 10 & 100.00 & 10 & 100.00 \\
\hline Age of dam & & $* *$ & & $* *$ & & $* *$ & & $*$ & & ns \\
\hline$\leq 2 \mathrm{yr}$-old or less & 15 & $86.67^{(13.33)}$ & 13 & $92.31^{(7.69)}$ & 12 & 100.00 & 12 & $91.67^{(8.33)}$ & 11 & 100.00 \\
\hline$\leq 3 \mathrm{yr}$-old & 14 & $92.86^{(7.14)}$ & 13 & 100.00 & 13 & $84.62^{(15.38)}$ & 11 & 100.00 & 11 & 100.00 \\
\hline$\leq 4 \mathrm{yr}-$ old & 15 & 100.00 & 15 & $93.33^{(6.67)}$ & 14 & 100.00 & 14 & 100.00 & 14 & 100.00 \\
\hline$\leq 5 \mathrm{yr}$-old & 19 & $94.74^{(5.26)}$ & 18 & $94.44^{(5.56)}$ & 17 & 100.00 & 17 & 100.00 & 17 & 100.00 \\
\hline$>5 y r-o l d$ & 7 & $85.71^{(14.29)}$ & 6 & $83.33^{(16.67)}$ & 5 & 100.00 & 5 & 100.00 & 5 & 100.00 \\
\hline
\end{tabular}

ns $=$ not significant, $* \mathrm{P}<0.05, * * \mathrm{P}<0.01$. Values in parenthesis reflect the mortality rate 


\section{DISCUSSION}

\section{Growth performance of lambs.}

The effect of breed on birth weight and subsequent weights of lambs is well documented. The early stages of growth are known to be strongly influenced by breed size, milk producing ability of the dam, the environment under which lambs are maintained, notably availability of adequate feed supply (Gatenby 1986 and Notter and Copenhaver 1980). The results obtained from this study are similar to the results obtained by Bata (1982) and El-Oksh et al. (1983) for Barki, Ossimi and Rahmani lambs and Abd-Allah (2005) for Rahmani, Chios and their crosses. The differences in birth weights between the findings of this study and those reported in the literature may be attributed to the breed differences in terms of their prenatal growth potential.

The differences in the average birth weights observed between both sexes may be due to differences in rate of skeletal development as well as the differences in the chromosomal structure during the prenatal growth period (Attalah, 1988). This is also in line with other findings where males are generally heavier than females. El-Oksh et al. (1983) found that male lambs excelled female lambs by $0.10 \mathrm{~kg}$ at birth. However, Barghout and Abd El-Aziz (1986), Attalah (1988), Hamdon (1996) and Abd-Allah (2005) reported that the differences between birth weights of the two sexes were not significant. Male lambs maintained their weight superiority at birth compared to females until yearling age and the difference was significant $(\mathrm{P}<0.01)$ at all stages. Sex differences in weights of lambs increased as lambs advanced in age. This phenomenon may be attributed to the action of sex hormones which play a major role in accelerating growth. Similar results were reported by Suliman, (1994) indicated that male lambs were heavier than females at different ages from 4 to 12 months of age.

The influence of birth type on growth performance is well documented by Tuah and Baah (1985). In this study, lambs born as singles had maintained their weight superiority at birth throughout the study period. Several workers reported similar effect of type of birth on body weight at different ages Hassan (1984) and Morsy (2002).

Least square means for age of dam in Table (1) showed that lambs born by ewes of 2 year old or less were non significantly lighter at different ages than those resulting from ewes of 3yr-old or more. These results agree with those reported by Hassan (1993) for Ossimi, Saidi and its crosses with Chios rams, who reported that the effect of age of dam was not significant. Also, Hassan and EL-Feel (1988) found that age of dam was not significant on lamb's body weight at all periods studied.

\section{Average daily gain (ADG)}

A daily gain of cross lambs was higher than the pure lambs at all stages of growth. The two breeds had an average daily weight gain less than $100 \mathrm{~g}$ /day after the second stage of growth. Similar findings of the effect of breed on average daily gain were reported by Hassan (1993); Hamdon (1996); Marzouk and Mousa (1998) and Abd-Allah (2005). Male lambs had significantly higher average daily gain compared to females (118.7 vs. $105.5 \mathrm{~g} / \mathrm{d}$ ) from $3^{\text {rd }}$ to $6^{\text {th }}$ months. These results are in agreement with Suliman (1994); Marzouk and Mousa (1998) who found that the effect of sex on daily gain was not significant.

The influence of birth type on growth performance is well documented by Tuah and Baah (1985). In this study, lambs born as singles had maintained their weight superiority at birth throughout the study period. In areas where there is seasonal fluctuation in availability of fodder, it might be advantageous to maintain fast growing single born lambs that could reach marketable weights in shorter period rather than attempting to improve prolificacy of ewes to increase the number of lambs born per parturition (Awgichew, 2000). These results are in agreement with those reported by Morsy (2002).

Lambs born from ewes of 2-year old or more had a significantly faster growth rate during suckling than those born from older ewes. These results may be attributed to the strong influence of the mothering ability of the dams on their offspring before weaning, as they greatly depended on their dams milk yield. The present results are in agreement with results of Barghout and Abd El-Aziz (1986) and Suliman (1994), who reported that the effect of age of dam on daily gain of lambs was not significant. On the other hand, Morsy (2002) reported that age of dam had a highly significant effect $(\mathrm{P}<0.01)$ on daily gain in all periods studied.

A result in the Table (3), which refers to the superiority of cross lambs for parents, is probably due to the impact of heterosis in the first generation. The present results are consistent with those reported by Hassan (1984); Hassan et al. (1985); Hassan and ElFeel (1988) and Morsy (2002).

\section{Lambs survival rate:}

The higher survival rate of Rahmani lambs during the first months of age could be due to their adaptation to the local conditions than exotic breed (Chios). In contrast, Chios lambs had maintained their high survival rate from $9^{\text {th }}$ months to yearling age, the higher survival rate during this period of Chios lambs may be due to their superiority in growth rate during the advancement period. Effect of breed on survival rate is consistent with results from other studies (Morsy, 2002 and Abd-Allah, 2005) who reported that breed group had insignificant effect on survival rate. On the contrary, El-Karim, (1993) and Hamdon, (1996) stated that breed group had a significant effect 
on survival rate, especially at early ages and becomes more important as age advanced.

The effect of sex on survival rate was not significant during all growth periods, except at birth. The survival rate of female lambs was significantly lower than that of male lambs $(94.74 \%$ vs. $90.63 \%$, $\mathrm{P}<0.05)$. These results agree with those reported by Hassan and Sallam (1988); El-Karim (1993); Hamdon (1996) and Abd-Allah (2005). They reported that sex of lamb had no significant effect on survival rate at all the studied periods. On the other hand, Dalton et al. (1980) indicated that females survived better than males. Furthermore, similar results were reported by Notter and Copenhaver (1980).

Increasing of survival rate of single born lambs than twins may be due to ewes in such circumstances will have poor milk yield to feed their lambs leading to a high lamb mortality, particularly within the first two weeks of birth, as indicated by Fitzhugh and Bradford (1983) or due to low birth weights of lambs born as twins. These results are agreement with those reported by (Hassan and El-Feel, 1988; Dalton et al. 1980 and Abd-Allah, 2005) who documented that single born lambs had better survival rate than twins or triplets. The high loss of lambs born to the first time lambing ewes during the first period of growth phase may be a result of the influence of lower birth weight and probably the lower milk producing ability of these ewes. Hamdon (1996) found that age of dam was a significant source of variation in survival rate of lambs. On the contrary, Hassan (1993); Suliman (1994); Marzouk and Mousa (1998); Morsy (2002) reported that the effect of age of dam on livability of lambs was not significant.

\section{CONCLUSIONS}

The main disadvantages of the Rahmani ewes are low prolificacy, average fertility and late sexual maturity. On the other hand the Chios breed excels in all three attributes. Preliminary results indicate that precocity is higher in the crossbreds than purebred lambs. Performance of crossbred lambs, especially those sired by Chios rams, exceeded that of the Rahmani lambs. It is concluded that Chios breed could be an appropriate breed for terminal sire crossbreeding to improve both Rahmani ewe's productivity and early lamb growth under Upper Egypt conditions system.

\section{REFERENCES}

Abd-Allah, M. (2005): Effects of crossbreeding between Chios and Rahmani sheep on some productive and reproductive traits. M. Sc. Thesis, Fac. Of. Agric, El-Minia Univ.

Attalah, G.E.Y. (1988): Studies on Fatting crossbred lambs. M. Sc. Thesis, Fac of. Agric, Al-Azhar Univ. Cairo, Egypt.
Awgichew, K. (2000): Comparative performance evaluation of Horro and Menz sheep of Ethiopia under grazing and intensive feeding conditions. Ph.D. Thesis. der Landwirtschaftlich-Gärtnerischen Fakultät. der Humboldt-Universität zu Berlin.

Barghout, A.A. and Abd El-Aziz, A.S. (1986): A comparative study of body weight and growth rate of Turkish and Barki lambs during the suckling period. Egypt. J. Anim. Prod. 26(1): 47-54.

Bata, S.S. (1982): Studies on intensive sheep production, comparative study on the production of cross lambs of the local sheep. M. Sc. Thesis, Fac. Of. Agric, Al-Azhar Univ. Cairo.

Dalton, D.C.; Knight, T.W. and Johanson, D.L. (1980): Lamb survival in sheep breeds on New Zealand hill country. N.Z.J. Agric. Res., 23: 167-173.

Drew K.R. and Reid J.T. (1975): Compensatory growth in immature sheep. 1. The effects of weight loss and realimentation on the whole body composition. J.of Agri. Sci (Cambridge) 85: 193-204

Düzgünęs, O.; Kesici, T.; Kavuncu, O. and Gurbutz, F. (1987): Research and experiment methods (Statistic Methods-II) Ankara Univ. Faculty of Agriculture Publications No: 1021, Ankara, PP: 381.

El-Karim, A.I.A. (1993): Survival rate to weaning in two types of Sudan Desert sheep. Bull. Anim. Prod. Afr., 41: 257-262.

El-Oksh, H.A.; Mabrouk, M.M.S.; Afifi., E.A. and Bata, S.S. (1983): The effect of crossing local breeds of sheep with Finnish landrace and Ilede-France and other factors on birth weight of lambs.Al-Azhar Agric. Rese. Bull. No. 96.

Fitzhugh, H.A. and Bradford, G.E. (1983): Productivity of hair sheep and opportunities for improvement. In: Fitzhugh, H. A. and Bradford, G. E. (eds.). Hair sheep of Western Africa and the Americas. A genetic resource for the Tropics. A Winrock International Study. Westview Press/ Boulder, Colorado. pp. 23-52.

Gatenby, R.M. (1986): Sheep production in the Tropics and Sub-Tropics. In Tropical Agriculture Series 351. CTA, The Netherlands. Longman Group Limited.

Hamdon, H.A.M. (1996): Studies on some factors affecting pre-weaning lambs performance. M,SC Thesis. Fac. of. Agric, Assiut, Univ.

Hassan, H.A. (1984): Studies on some of the Egyptian sheep and their cross under Minia environmental conditions.Ph.D.Thesis in Fac, Agric, Minia.Univ

Hassan. H.A. (1993): The effect of crossing Chios rams with Ossimi and Saidi ewes on growth 
performance and viability of lambs. Egyptian. J. Anim. Prod.30: 39-53.

Hassan. H.A and El-Feel, F.M.R. (1988): The effect of crossbreeding among Ossimi, Barki, and Saidi sheep and some other factors on body weight and daily gain of lambs. Minia. J. Agric. Res.10: 1607-1628.

Hassan, H.A and Sallam, M.T. (1988): The effect of crossbreeding and other factors on livability of lambs raised under middle Egypt conditions. Minia. J. Agric. Res.10: 721-737.

Hassan. H.A.; Ahmed, I.A.; Sallam, M.T.; El-Kimary, I.S and Toney, S.M. (1985): Some factors influencing body weight and livability of Egyptian sheep and their crosses under the environmental condition of middle Egypt. Annals of Agric. Sci. Moshtohor, 23 (2): 635-646.

Marzouk, K.M. and Mousa, M.T. (1998): A study on some economic characteristics in Awassi sheep in Egypt: J. Agric. Sci. Mansoura. Univ. 23: 4773-4780.

McManus, A.R.; Reid, J.T. and Donaldson, L.E. (1972): Studies of compensatory growth in sheep. J. of Agri. Sci (Cambridge) 79: 1-12.

Morsy, A.H.A. (2002): Evaluation of prolific and nonprolific breeds of sheep under the environmental condition of middle Egypt: PH.D Thesis. Fac. of. Agric, El-Minia. Univ.

Notter, D.R. and Copenhaver, J.S. (1980): Performance of Finnish Landrace crossbred ewes under accelerated lambing. II. Lamb growth and survival. J. of Ani. Sci 51(5): 1043-1050.

Rastogi, R.K.; Keens-Dumas, M.J. and Lauckner, F.B. (1993): Comparative performance of several breeds of Caribean hair sheep in pure breeding and crossbreeding. Small Rum. Res. 9: 353-366.

S.A.S. (1998): Statistical analysis system. SAS USER'S Guide: Statistics. SAS Institute Ine. Editors, Cary, NC.

Suliman, A.I.A. (1994): Improvement of some Ossimi productive and Reproductive traits through crossing with Chios breed of sheep. M.SC. thesis. Fac. of. Agric, Minia Univ.

Thornton, R.F.; Hood, R.L.; Jones, P.N. and Re, V.M. (1979): Compensatory growth in sheep. Aust. J. of Agri. Res. 30: 135-151.

Tuah, A.K. and Baah, J. (1985): Reproductive performance, pre-weaning growth rate and preweaning lamb mortality of Djallonke sheep in Ghana. Trop Anim Health Prod 17(2): 107-113.

\footnotetext{
خصائص النمو، ومعدلات الحيوية للحملان النقية والخليطة فى ظل نظام الرضاعة غير المحدودة محترم عبل الله محمد /براهيم

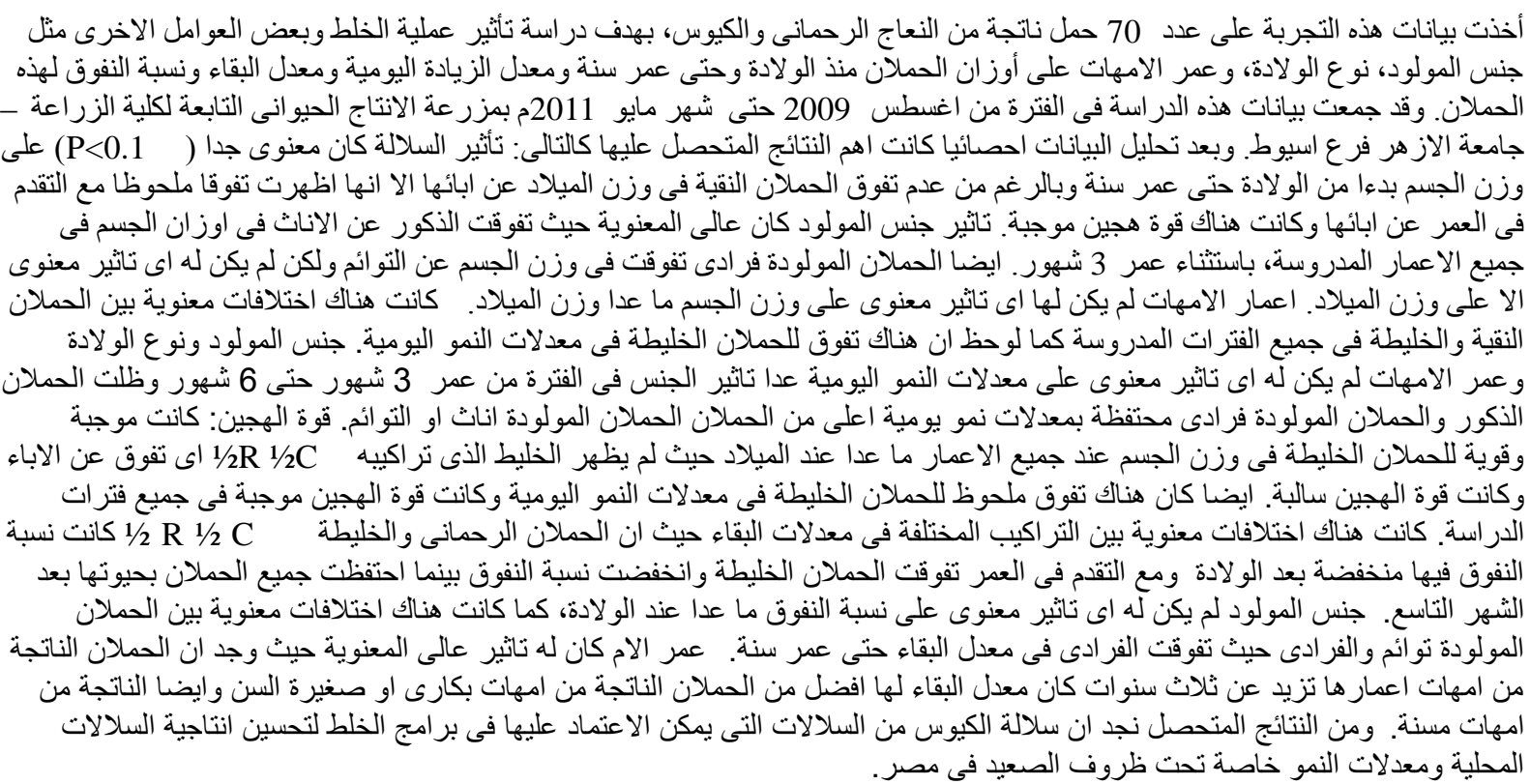

